\title{
Africanisation of theological education: An exploration of a hybrid epistemology
}

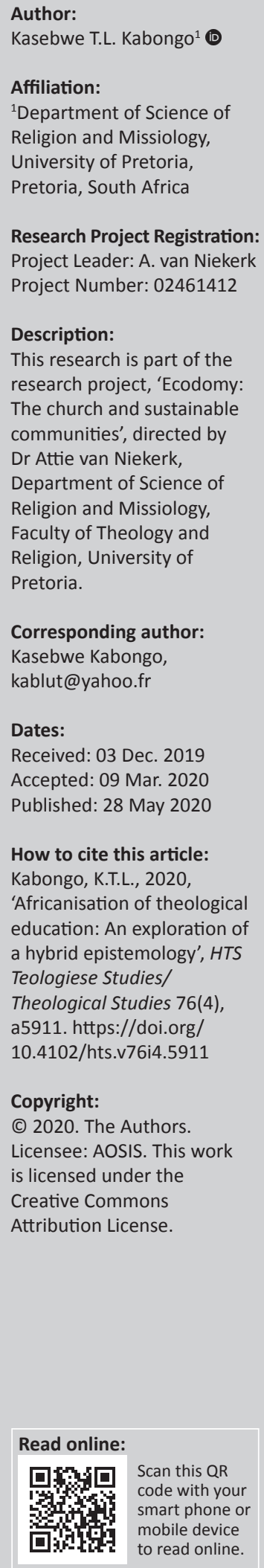

This article explores the concept of hybrid epistemology in relation with the author's theological teaching of his neighbours from the northern townships of Pretoria and the students of the University of Pretoria. It is written from the perspective of a black African mission practitioner who values with equal footing the diverse ways human beings can acquire knowledge. He longs to see a symbiotic relationship between different epistemologies and be prioritised in the theological training of Africans. He stresses that the value in authenticity would allow the diversity of epistemologies to weave together in a symbiotic way. This article is a case study that reflects on the symbiotic relationship between different epistemologies using the five human senses as a multi-sensory approach to knowing. It discusses the experiences with students from InnerCHANGE and the University of Pretoria.

Keywords: Africanisation; authenticity; human senses; hybrid epistemology; multi-sensory; transformation agents.

\section{Introduction}

The Africanisation of theological education is an ongoing conversation. This article aims to contribute in a small way to this conversation. It reflects on my experience as a practitioner of theology in black African communities living in poverty. In these communities, I teach theology with a keen interest to Africanise it. Several African scholars have been calling for the Africanisation of theological education in the current post-colonial Africa (Andraos 2012; Dolamo 2017; Hadebe 2017; Mashabela 2017; Mbembe 2015; Naidoo 2016; Nyamnjoh 2004). Naidoo's (2016:1) understanding of Africanisation is helpful here. According to her, Africanisation is 'a renewed focus on Africa'. This article understands the Africanisation of theological education as a focus on Africa that would develop theology students into assets to the building of Africa, starting from their local communities. South African communities of poverty and Africa, in general, face several issues that negatively affect the quality of life of people. This article stresses that theological education should train students to proactively participate in addressing such issues that affect their communities of residence.

A few years ago, I (the author) was invited to teach the module 'Mission in practice' at the University of Pretoria. I accepted the invitation. I thought that theological education at the university was pursued by people with a vocational calling to ministry like it was in my case. The reality was that the majority of my students did not feel a calling to ministry and pursued theological education so that they could get a degree and then a job in the market place like any other university graduates. Many of these students did not even identify themselves as Christians. This realisation made me wonder how theological education could be relevant to such students.

The University of Pretoria reality unexpectedly had some similarity with the apprenticeship the organisation I belong to, InnerCHANGE, runs (innerchange.org 2019). In this apprenticeship, theological education is given to emergent leaders from the northern townships of the city of Pretoria. Many of these leaders do not feel called to full-time vocational ministry. The curriculum is geared more towards hands-on training (80\%) than theoretical (20\%) knowledge accumulation. This apprenticeship aims to develop transformation agents. The latter are (Kabongo 2019a):

Individuals who generally observe principles of human dignity and worth, human rights, good social values, and individual and socio-political transformation ....They are able to recognise the existing needs of individuals and a community, and engage them in a way that is solution-seeking. Their engagement usually leads to new insights into ways to heal or build a community through its residents. (p. 7)

InnerCHANGE trains transformation agents to see their role within the church as well as in society as that of building up. They strive to be agents of blessing in society. I am attempting to design 
curricula that will help develop theology students from both InnerCHANGE and the University of Pretoria as transformation agents. The multi-sensory approach to learning is the pathway I currently explore. InnerCHANGE curriculum is already using this approach. I am trying to bring this approach to the University of Pretoria. This article is a case study that reflects on what happens at InnerCHANGE and what I am trying at the University of Pretoria. Polit and Beck (2008:235) describe case studies as 'in-depth investigations of a single entity or a small number of entities'. This reflection seeks to pursue a mutually beneficial relationship between the academia and African communities of poverty so that theological education can be an asset in the building of Africa. It is, therefore, grappling with the question: How can theological education proactively participate in building Africa? A hybrid epistemology is suggested as a framework.

Some time ago, I had a conversation with a senior scholar about the level of literacy in theology students. He stressed that 'the academia is all about these three words: read, repeat and write' (Kritzinger 2019). If a student is not good at any of those words, he or she cannot succeed academically. The reality is that some students are not good at some of those words. There, therefore, is a need to diversify methodologies of teaching with the hope of being inclusive in knowledge impartation. InnerCHANGE is exploring that. This exploration is performed with a certain understanding of the purpose of education learnt from the ancient Latin world. The latter stresses 'not for school, but for life do we study' (De Give 1961:xvii). This understanding is further deepened by De Beer and Van Niekerk (2017:216-217) who believe that theological education should 'serve the public good in the broadest possible sense'. Someone's inability to read and write that does not necessarily disqualify them from being an asset to lives around them or to be a proactive agent of the public good. It is also problematic for theological education to remain confined in the read-repeat-write format if our society needs any wisdom it can get for lives to be improved. The Bible, which is the foundation of Christian theology, contains some wisdom that could promote positive engagement in the building of Africa. This conviction has motivated this article to reflect on hybrid epistemology.

\section{Hybrid epistemology}

The concept of hybrid epistemology is inspired by epistemological diversity. The latter alludes to (University of Pretoria 2019):

\footnotetext{
... bringing marginalised groups, experiences, knowledges and worldviews emanating from Africa ... to the centre of the curriculum. It involves challenging the hegemony of Western ideas and paradigms and foregrounding local and indigenous conceptions and narratives, while recognizing the global context. (p. 1)
}

Biblical principles challenge the epistemological hegemony of one way over the others. McMinn (1998:24) stresses that 'biblical teachings encourage Christians toward a religious praxis that is welcoming of different peoples as equal partners in faith'. This is why theological education in Africa must encourage 'greater pluralism' in knowledge impartation (Fubara, Gardner \& Wolff 2011:115).

However, the affirmation of epistemological diversity seems to result in the hegemony of one way of knowing over the others. Naidoo (2015:2) stresses that 'generally diversity remains an elusive and ambiguous concept not devoid of paradox'. There is already a powerful, dominant and wellestablished way that has worn universal colours for decades. The political analyst A. Mashiqi ([Power FM Radio Station] pers. comm., 06 October 2019) once said: 'In sub-Saharan Africa, the majority people are a minority culture in terms of dominance. The dominant narrative, logic, power is held by the minority people'. As black Africans, we may be partly responsible for such an unfortunate situation because many of us may be suffering from an inferiority complex. Ramphele (2017) stresses that:

[F]reeing ourselves as black people from the inferiority complex imposed by a system that apportioned value and human dignity according to a colour code remains the most important stepping stone to true freedom. (p. 22)

This is why calls for the Africanisation of education have not yielded much result, although it started at the dawn of the post-colonial Africa (Duncan 2000:23). Fanon (quoted by Honenberger 2007:xvi) says that this situation 'denotes a scaled inferiority in which the indigenous culture is devalued by' everyone, including indigenous people themselves. Naidoo (2016:1) says that 'much of what has been taken for theological education in Africa is in fact not African but rather a reflection of Europe in Africa'. Some black African theologians have also contributed to the establishment of the hegemony of Western epistemology. Pei describes such contribution as cosmetic. This means that these black Africans have just learnt to write, teach and assess students 'more like whites in order to fit in with the dominant culture' (Pei 2018:39). Andraos (2012:6) stresses that 'Eurocentric approaches are dominant in the field of theology influencing both the content and the way knowledge is communicated'. The black African challenge is to ask the question: 'How do we include voices and sources from other cultural perspectives in our' knowledge impartation (Andraos 2012:7).

This question is asked with the hope that 'through intercultural learning students can bring different knowledge from their respective traditions. In this way local knowledge and wisdom is valued with multiple theoretical frameworks' (Andraos 2012:10). For inter-cultural learning to happen, individual black Africans need to learn to be authentic. Authenticity 'is the quality of being genuine, or real' (dictionary.com 2019).

Joseph (2016:1-2) says that '... authentic people ... are accepting of themselves and of other people ... are able to express their emotions freely and clearly ...'. The synergy between epistemological diversity and authenticity will birth a hybrid epistemology. 


\section{What is hybrid epistemology?}

This reflection is based on my self-introspection. My identity is a hybrid of epistemologies. What I know comes from reading, hearing (stories, radio, conversations with people), seeing, smelling, testing, tasting, touching and feeling. I understand best from doing something. I am a hybrid of diverse ways of knowing. I deeply resonate with this old Chinese proverb: 'When I hear, I forget. When I see, I remember. When I do, I understand'. I understand things in a diversity of ways that have built my knowledge capital. Habede (2017:7) understands this as pluriversalism because it 'attributes equal status to multiple forms of knowledge'. For Mbembe (2015:4), 'pluriversalism is open to epistemic diversity. It is ... a horizontal strategy of openness to dialogue among different epistemic traditions' so that synergy and harmony can take place. For synergy to take place fruitfully, the value in authenticity should be in place. Authenticity, as defined in the previous section, will equip black Africans to substantially challenge the current 'Eurocentric universality claim' in the production of academic knowledge (Naidoo 2016:2). Authenticity will be meaningful if it is embedded in the daily reality of an ordinary African. Value of authenticity will give birth to a theology that has the 'ability to inspire people to be agents and embodiments of the life of God's new creation in Jesus Christ' (Kirk 1997:7). Such a theology will prepare students (Nyamnjoh 2004):

$[T]$ o be relevant in the communities in which they are serving and working by trying to ensure that they are relevant to African contexts (Naidoo 2016:2). It will promote African creativity, agency and value systems. (p. 160)

It will promote 'human rights culture and dignity' (Mashabela 2017:1). It will equip students to proactively engage (Dolamo 2017):

[...P] resent-day challenges, especially on the socio-economic front. For instance, the scepticism that was directed at white liberals since the 1960s should now be directed at 'monopoly capital', irrespective of whether it refers to black or white businesses. (p. 7)

It would also equip students to proactively function in their African contexts as well as globally (Naidoo 2016:1), starting from their context of residence. It has the potential to be 'transformative because it will engage with local realities' (Niemandt 2019:4). The Africanisation this article proposes stresses about learning from concrete African realities in which students will learn from doing.

I have been experimenting with this hybrid epistemology model with the InnerCHANGE apprenticeship students. I reflect on my learning in the section below:

\section{A framework of curriculum design}

I have designed a curriculum for Inner CHANGE apprenticeship, which is primarily action oriented, whose primary lecture hall is the streets of townships and which had the end in mind of developing theology students as proactive participants in community building. The designing process took into consideration the five human senses. It was inspired by this statement: 'Philosophers have hitherto interpreted the world in various ways, the point is to change it' (Karl Marx quoted by Fischer 2006:360). Over the past few years, I read extensively and attended conferences about the transformation and/or Africanisation of theological education, which has been very helpful. The task here was to interact with this accumulated knowledge in a way that knowledge impartation will lead to the agency in community building founded on biblical principles. Hayes (2006:113) stresses that theological education must be carried out 'in a way that can be seen, heard and handled'.

A reflection on the five human senses provides a good framework to be inspired by how human senses allow us to know or learn in a particular way, including how these unique ways of knowing or learning synergise into a hybrid package that helps describe an individual's epistemology. Referring to the five human senses, I am aware that 'learning is an individual process, and what works for one person may not work for another' (learnthroughexperience.org 2019). Therefore, it is critical to diversify pathways of learning. Because there is research evidence showing that 'only certain parts of the brain activate during learning; therefore, visual learning will activate a different part of the brain than would olfactory learning, for example' (learnthroughexperience.org 2019). The curriculum design intended to be inclusive of different ways of learning and for those differences to weave together in a symbiotic way. Shams and Seitz (2008:1) point out that 'our experience in the world involves constant multisensory stimulation ... Therefore, it is likely that the human brain has evolved to develop, learn and operate optimally in multisensory environments'. They also stress (Shams \& Seitz 2008):

Most objects have multisensory representations. Most abstract notions can be communicated using multiple media (e.g. by written words or images, by auditory articulation or their natural sounds) ... educators have empirically noticed that multisensory training for various tasks is more effective than the traditional unisensory training schemes ... (p. 5)

The effectiveness is explained by the fact that 'taken together, the full range of senses helps students learn material in a more concrete manner' (learnthroughexperience.org 2019). Also, Treichler (1967:5) states: 'People generally remember $10 \%$ of what they read, $20 \%$ of what they hear, $30 \%$ of what they see, and $50 \%$ of what they see and hear'. The synergy of these percentages leads to better outcomes. It is, therefore, ideal to impart knowledge in a way that $100 \%$ of the teaching could lead to concrete outcomes. For InnerCHANGE, the outdoors was the place that maximised this ideal. Simon (2019:1) thinks that 'the outside world shapes [students] development through experiences that they have, which include using their five senses - hearing, sight, smell, taste, and touch'. 


\section{The multi-sensory curriculum}

This section details the process of designing the curriculum using the multi-sensory framework.

Our InnerCHANGE curriculum is shaped around Micah 6:8. The latter inspired the division of our curriculum into three chapters: the prophetic (act justly), the missionary (love mercy) and the contemplative (walk humbly before your God). I attempted to incorporate learning through the five human senses into all the chapters of the curriculum. Wortman (1988:1) advises that 'learning takes place when the mind is able to put together information from all the senses and make a connection with past learning'. It is, therefore, imperative to represent all the five senses in a balanced way as pathways of knowledge impartation. Such a representation would push back the currently held belief on 'knowledge hierarchies' valuing the academia over 'local, community or indigenous knowledge and wisdom ...' (De Beer \& Van Niekerk 2017:237). Below is how the intention to include all the human senses plays out in the curriculum design.

\section{Sight}

The curriculum design pictures the streets of townships as the primary lecture hall of apprentices as opposed to the traditional space surrounded by four walls. It stresses a great deal about taking apprentices to the streets of neighbourhoods to see, notice and reflect on what was observed. It also includes written words on posters, the Bible to be read and interpreted, pictures and videos. I am learning that 'humans are primarily sight-oriented. Everything, from the foods we eat to the clothes we wear, shows signs of visual influence' (Simon 2019:3). Kouyoumdjian (2012) points out that:

[... O] ur brain is mainly an image processor ..., not a word processor ... the part of the brain used to process words is quite small in comparison to the part that processes visual images. (p. 1)

Below is how the visual was included in the three chapters of our curriculum.

In the prophetic chapter, the goal is to train apprentices who are all local leaders to not be normal, but agents of the kingdom. We take them out to the streets of our neighbourhoods through prayer walk and task them to look for signs of blessing as well as signs of trauma in their neighbourhood. We want them to start looking at their community with new and fresh eyes. The latter aims to challenge them to learn to see blessings around them and join God as agents of the expansion of his blessings to their community. We also want them to learn to notice signs of trauma such as bullets lying on the streets, health hazards such as open sewage, garbage at many spots in the community, drug addicts at street corners and neglected children roaming around the neighbourhood so that they can become part of the solution in the healing process of the trauma around them. We want them to have the visual of what God is calling his church to grapple within society so that we can concretely talk about how God is calling us to respond to his calling.

Our end in mind is to develop a band of people who are not normal. In our communities of poverty, it seems like being normal is accepting of the status quo and being passive in social intervention. Ramphele (2017:27) stresses that it is important to refocus on the need to build ourselves into the country of our dreams'. We use the sense of sight as an entry point of our learning of nurturing agency. We believe that to influence people, it is important to help them to 'think about themselves and how they regard themselves and how they regard their history and culture ...' creatively (Clarke 1991:57). Mbembe (2007) states:

... [Our] ability to effect meaningful social changes is substantive ... For black solidarity to serve as a political and moral resource ..., it needs to be defined not only to deal with new social realities but, even more importantly, to conform better to democratic principles ... it must be rooted in a commitment to equal justice for all - a commitment to enable all voices to be heard ... (p. 144)

The sense of sight also shaped how to train our apprentices to love mercifully. InnerCHANGE serves communities through service projects such as tutoring, sports, home-based care, drama club, and children and teenager mentoring groups. When people sign up to join our apprenticeship, we place each one of them in one of our existing projects so that they can learn from seeing, then imitating, gain confidence in doing things independently and learn to teach others to learn from seeing.

The sense of sight also plays a role in how we train our apprentices to learn to walk humbly before their God.

We include many images (photos and videos) in teaching. We find it important to teach apprentices to start from the known (building a relationship with someone else), to learn to build a friendship with the invisible God. Niemandt and Beyers (2017:159) advise that teaching be performed 'by means of symbols and metaphors'.

The traditional academic way of teaching through reading, repeating and writing is also included in this visual part $(20 \%$ of the curriculum). Apprentices are recommended to read several chapters of books and summarise them either in writing or orally and share with the group what they have learnt.

\section{Hearing}

We also know through our hearing. In townships and other communities of poverty in sub-Saharan Africa, the sound is a significant part of our day-to-day life. Many of us speak loud in private or formal settings. My family house is sandwiched between a tavern and a Pentecostal church. Both of these institutions are known for having very noticeable sounds. Those sounds are both disruptive and a learning platform 
about how to be agents of hope in society. Our curriculum teaches apprentices to learn to embrace those sounds (de) constructively because they are part of daily realities such as the hooting of taxis, the cries from funerals and babies, the sounds of music from homes, and noise of car speedsters showing off their driving prowess. We are learning that 'hearing helps people learn associations. ... Hearing invites to learn to distinguish right from wrong, and safety from danger, and it is a crucial part of learning throughout life' (learnthroughexperience.org 2019:3). Hearing exercises were included in the three chapters of our curriculum, which are as follows:

In the prophetic chapter, where apprentices are taught to wear new eyes, we sometimes prayer walk silently listening to the sounds around us and reflect on what we heard. Reflection is conducted in small groups as well as the big group of everyone where apprentices listen to one another under the facilitation of a mentor.

All the apprentices serve in existing InnerCHANGE projects. At the end of every month, apprentices and their leaders make home visits to the beneficiaries' families. The purpose of these visits is to hear from the beneficiaries' parents or guardians about the impact of our programme on their child(ren). We debrief together what we heard and what we learned. The outcome of these debriefs helps in shaping meaningful programmes for our beneficiaries.

Our curriculum also incorporates a substantial amount of group work, which has to do with interactively listening to one another.

Our apprentices work on a team with peers and mentors in the different service projects we run. They pray and plan together, and carry out a debrief at the end of the programme, which involves listening to one another. The prayer walks we perform involve listening to God. They sometimes involve listening to God's message in our lives through the voices of our neighbours.

\section{Taste}

Tasting can be a way to learn how to make associations as well as to be associated with a context. Most cultures have a specific way of cooking certain kinds of food, for example. An awareness of different tastes can help someone know who they are leading and how to interact with them. Tasting can also help someone know that the food is edible or not, and whether a drink is alcoholic or not.

In the prophetic chapter, apprentices are taught to prioritise standing in solidarity with their neighbours. Biko (2007:156) advises us 'to rally together with' our neighbours in ways that promote humanity so that we can be tangible agents of love. We, therefore, attend many functions, primarily funerals because they are the most regular in occurrence. At these functions, we eat. One thing we have learnt from tasting is that food items seem to be the same regardless of whether it is a funeral or a wedding. A key lesson has been that functions are held to celebrate life. Another lesson is the cultural value of fitting in by doing things the same way as others. This custom influenced the theme of not being normal, but kingdom like.

In our formation of merciful lovers, we teach our apprentices to cook. Hospitality is a value in the culture and food is a big part of that. We sometimes cook for our beneficiaries and at other events. We cook for our apprenticeship sessions. Apprentices work in groups of two and rotate to cook for the group. The latter gets to enjoy different tastes and interacts with the value of diversity we are all called to uphold as Christians.

An important part of our teaching in contemplation is a regular celebration of Holy Communion. The latter is a significant way to remember Jesus as the epicentre of our apprenticeship and lives. Holy Communion covers the senses of sight, taste and touch.

\section{Smell}

The sense of smell is part of how to try to impart knowledge. In our walks in the streets of townships, we have learnt to be attentive to the smell around us. Some smell communicates a season, a situation or a condition.

A season of protest when garbage bins are not collected weekly is prominent. Many neighbours will dump their garbage at the nearest open space in the community.

The smell of sewage is a common occurrence that communicates how municipal authorities take seriously service delivery issues.

InnerCHANGE works with various children. We are learning to smell when they are sick or are not well taken care of at home. Such smell leads us to investigations through home visits. Our heart behind this process is to participate in 'the improvement of the quality of life' of the people we serve (Van Niekerk 2015:1).

Someone can acquire knowledge through smell. Hamann (ed. 2019) points out that an 'odor [sic] can trigger a memory from years before ... And a scent activates more parts of the brain than sight alone'. Her research finding points out the impact of smell on learning, memory and knowledge acquisition.

During the prophetic chapter, prayer walking improves our awareness of smell and what to learn from it.

As learners of what it means to be merciful lovers, in our work with children, smell teaches us to pay attention to a specific child, reach out to their primary caretakers and learn about their life circumstances so that we can serve such a child to the best of our ability. 
In our contemplative learning, we sometimes venture into nature through going to a park or garden and learn to connect with God through the smell of beautiful flowers, grass or trees.

\section{Touch}

The sense of touch is critical for experiential learning. In the InnerCHANGE apprenticeship, we have seen a great deal of positive learning outcome when we involved touching in our teaching. The actual act of touching helps bring up 'a series of emotions and memories that aid in learning' (leranthroughexperience.org 2019). It is estimated that '30 to $40 \%$ of people are considered tactile learners, the ability to touch while learning could be vital' in their knowledge acquisition (Gilakjani \& Ahmadi 2011:470). In the traditional lecture room where we spend $20 \%$ of our teaching time, we have seen fruitful interaction when we had activities involving touch.

During the prophetic chapter, we walk in streets and in buildings for engagement with different officials. We get to touch with our feet and hands the buildings in which many of the decisions that affect our neighbours are taken. We also get to shake hands with different partners we collaborate with, and government officials we ask questions to or try to hold accountable for one thing or the other.

As learners of what it means to be merciful lovers, we involve our apprentices in manual service projects such as cleaning communal places, and painting or making a volleyball and netball court from a dirty and trashed communal area. All these projects are manual and teach our apprentices about the kind of leaders Christians are expected to be. We train them to become servants 'with the mission to help lives flourish' (Kabongo 2019b:3). Through these projects, we also want to communicate the message of what InnerCHANGE stands for: care of our environment, use what we have to bless others and learn by doing.

In the contemplative chapter, we teach our apprentices to pray by touching. Some of them have been able to sense something deeper in their heart and share it with the group.

In 2017, I started teaching the module 'Mission in practice' at the University of Pretoria. I have been trying to incorporate the multi-sensory learning in my teaching to diversify ways students can acquire knowledge.

\section{Teaching 'Mission in practice' at the university}

I took over a module that was designed by Attie van Niekerk, who had retired. The module's main focus was household visits that were to be made in a poor community. The goal of the household visits was 'to build a relationship with the families and to understand the life world of vulnerable children in the different communities ...' (Van Niekerk 2015:1). The module was designed to be $60 \%$ theoretical with students attending formal lectures on the university campus and $40 \%$ fieldwork in which students were tasked to build a relationship with a family raising a child.

The household visits were the most attended by students. Formal lectures did not have good attendance unless there was a test or assignment to be conducted in class on that day. Household visits provided a diversity of learning for students and were more of an oral exercise that the majority of the students preferred. They, however, had to be assessed in writing and orally. In the written and oral assessments, the students mentioned their take away from the module, which is shared below:

- Many of them learned that poverty does not have a skin colour in South Africa.

- Illegal immigration seems to harm the children's quality of life. Many migrant workers leave their children behind; only a few of them can reunite with their children at some point.

- Many Christian non-profit organisations are participating in the common good by serving children in various ways.

- There seems to be a connection between poverty and the lack of family planning.

- Racism is still a reality. Some students of colour were racially abused by a person we visited.

- There was a general sense of dependency on the government to provide solutions to all societal problems.

Walking in the different streets of communities of poverty challenged the students to reflect on what poverty means for them. The definitions of poverty given by Bryant Myers and John Hayes helped catalyse our discussions. The former defines it as 'the absence of shalom in all its meanings' (Myers 2011:82). The latter defines it as 'absence of love' (Hayes 2019:1). The students' take away and the chosen definitions of poverty have challenged me to design a module that would equip students to be proactive builders of shalom communities and agents of making love present. A shalom community is 'an environment where socioeconomic justice is available to all and community's problems and their resolve is a concern for all' (Linthicum 2003:38). This article stresses that good amount of time outdoors has the potential to develop theology students into shalom community builders who study for life, not for school only. I will also expose them to a multi-sensory way of learning, which could maximise on what they can learn and remember. I would have preferred that the students from the University of Pretoria spend $80 \%$ of their time in a community of poverty building relationships with families, and only spend $20 \%$ of their time in lectures provided on the university campus. This is not yet possible because of budget restrictions. Field trips provided a platform for students to be in touch with a real context. The knowledge acquired from those trips did not only come from the lecturer. Theology education could equip students to be social workers because many churches are involved in serving communities larger than their congregations. The focus of the module is on household visits, which is a social issue that social workers spend much of their time on. Theology could 
partner with social work departments to restore the traditional strategic place of a family in the African society. Van Niekerk (2015) says:

The household has always been the centre of social, economic and religious life in African culture ... the past decades seriously weakened this centre, and has contributed to many of subSaharan Africa's most pressing problems ... The household and family must be re-established and strengthened if we wish to combat poverty and become a prosperous, growing and peaceful region. (p. 3)

For the church to be able to make a meaningful contribution, theological education could prioritise the students' understanding of a real-life context. Hayes (2006:15) points out that 'seeking the spiritual, social and environmental of [communities] is more significant in our collective future together than ever before'.

Van Niekerk (2015:4) advises to use the liberation theology method of 'first to look and listen (in order to understand) then think (in order to know the pitfalls and possibilities - and (only then) act (in order to really help)' in the process of seeking our collective welfare. Such a process has the potential to help students get a tangible understanding of a social problem and explore the possibilities of being part of the solution. This process will also require a reflection on what a helpful assessment is. At InnerCHANGE, we assess students by their ability to pioneer, sustain or maintain an initiative or a project in which they live out Micah 6:8.

Through such initiatives, they can be proactive participants in the public good. At the University of Pretoria, assessment is only performed in a written or oral form. Although these are globally recognised forms of assessment, successful students are not necessarily those who understand the reality of life of a certain community. This article stresses that theological education can only make a meaningful contribution in a real issue such as strengthening the African family if students are intentionally exposed to contend for families in an actionreflection approach.

\section{Reflection}

The multi-sensory way of learning has influenced InnerCHANGE design of its apprenticeship curriculum with the concept of hybrid epistemology in mind. This curriculum focuses much on experiential learning. The rationale behind it is to help students understand by doing. A curriculum that is designed with five human senses in mind has the potential to produce understanding in students because 'our senses work together to give us a total picture of our experiences' (Wortman 1988:1). The use of five senses in its curriculum design has improved InnerCHANGE efforts to be contextual and visible, and has helped raise human capacity from within communities of poverty. Niemandt (2014:42) stresses that 'theology must serve context, and context informs theology'. De Beer and Van Niekerk (2017:214) stress that theological education must have 'a transformational impact on people, communities and the construction of theology itself', because it should train people to be 'rooted in a lived faith'.

Botman (2012) stresses that theological formation should:

[L]earn to pick a side. And that side should be the public good. In sub-Saharan Africa, the public good is a choice for the marginalised, for the poor and for struggling communities. (p. i)

He stresses that if theological institutions 'follow this route', they will start 'concretely contributing to the remaking of the world' (Botman 2012:i). The desire to make such a contribution will experientially prepare theology students to proactively participate in the dialogue of life and action in their contexts of service. Bevans and Schroeder (2004) say that:

[T] he dialogue of life is the way in which we live with people of other convictions in the affairs of daily life, and the dialogue of action is the way in which we work together to solve problems that threaten all of us. (p. 383)

It is therefore imperative to train theology students in a way that 'emphasizes collaboration with local communities, congregations or organisations in finding solutions for societal challenges' (De Beer \& Van Niekerk 2017:241). Therefore, this article understands the Africanisation of theological education as learning to start with African communities as lecturing hubs, facilitate the students' understanding of real issues of Africa and equip them to participate in being part of the solution to these issues. The use of a multi-sensory approach to teaching has been a helpful tool for InnerCHANGE.

\section{Conclusion}

This article reflected on the Africanisation of theological education in its exploration of a hybrid epistemology as a method to bring about an effective way to develop theologians who are community builders. It defined a hybrid epistemology as a symbiotic relationship between epistemological diversity and authenticity. The epistemological diversity was captured in the multisensory framework of the five human senses InnerCHANGE uses in the theological training of its apprentices. This is the same method I am learning to introduce at the University of Pretoria. This approach sees a real African context as the primary space where students spend the majority of their time. It also explores a different method of assessment, which is not yet acceptable in academia. I see students as assets to the building of Africa. This article hopes to see theological education become a relevant actor in the development of students as effective and proactive answers to our many societal issues.

\section{Acknowledgements Competing interests}

The author has declared that no competing interest exist. 


\section{Author(s) contributions}

K.T.L.K. contributed solely to this research article.

\section{Ethical consideration}

This article followed all ethical standards for a research without direct contact with human or animal subjects.

\section{Funding information}

This research received no specific grant from any funding agency in the public, commercial or not-for-profit sector.

\section{Data availability statement}

Data sharing is not applicable to this article as no new data were created or analysed in this study.

\section{Disclaimer}

The views and opinions expressed in this article are those of the author and do not necessarily reflect the official policy or position of any affiliated agency of the author.

\section{References}

Andraos, M.E., 2012, 'Engaging diversity in teaching religion and theology: An intercultural de-colonial epistemic perspective', Teaching Theology and Religion 15(1), 3-15. https://doi.org/10.1111/j.1467-9647.2011.00755.x

Bevans, S.B. \& Schroeder, R.P., 2004, Constants in context: A theology of mission for today, Orbis Books, New York, NY.

Biko, S., 2007, 'Black consciousness and the quest for a true humanity', in C. Van Wyk (ed.), We write what we like. Celebrating Steve Biko, pp. 151-163, Wits University Press, Johannesburg.

Botman, R., 2012, 'Foreword', in B. Leibowitz (ed.), Higher education for the public good: Views from the South, pp. xiii-xv, SUN Media, Stellenbosch.

Clarke, J.H., 1991, Africans at the crossroads: Notes for an African world revolution, Africa World Press, Trenton, NJ.

De Beer, S.F. \& Van Niekerk, A.S., 2017, “"Transforming curricula into the next century: Doing theology collaboratively with local communities", in "Theology at the University of Pretoria - 100 years: (1917-2017) past, present and future"', Verbum et Ecclesia 38(4), a1683. https://doi.org/10.4102/ve.v38i4.1683

De Give, M., 1961, Grammaire latine, De Boeck, Liege.

Dolamo, R.T., 2017, 'The legacy of black consciousness: Its continued relevance for democratic South Africa and its significance for theological education', HTS Teologiese Studies/Theological Studies 73(3), a4587. https://doi.org/10.4102/hts. v73i3.4587

Dictionary, 2019, viewed 13 November 2019, from www.dictionary.com.

Duncan, G.A., 2000, 'Theological education: Mission birth - African renaissance', Missionalia 28(1), 23-40.

Fischer, S., 2006, 'C Having Hitherto interpreted the world, the point is to change it', African-American Studies. viewed 10 October 2019, from https://onlinelibrary. wiley.com.

Fubara, E.I., Gardner, M.T. \& Wolff, J.S., 2011, 'Applying diversity management principles to institutions of Christian higher education', Christian Higher Education 10(2), 112-131. https://doi.org/10.1080/15363751003715767

Gilakjani, A.P. \& Ahmadi, S.M., 2011, 'The effect of visual, auditory and kinaesthetic learning styles on language teaching', in J. Brutt-Griffler \& D. Perrin (eds.), International conference on social science and humanity, IPEDR, IACSIT Press, vol. International confe
$5, \mathrm{pp} .469-472$.

Hadebe, N.M., 2017, 'Commodification, decolonisation and theological education in Africa: Renewed challenges for African theologians', HTS Teologiese Studies/ Theological Studies 73(3), a4550. https://doi.org/10.4102/hts.v73i3.4550

Hamann, S., 2019, 'Editorial note', in Hamann, S. (ed.), Neuropsychologia, vol. 135, pp. 1-12 Elsevier, London.

Hayes, J.B., 2006, Sub-merge. Living deep in a shallow world: Service, justice and contemplation among the world's poor, Regal, From Gospel Light Ventura, Ventura, CA.

Hayes, J.B., 2019, Speech about starting new teams at the Cambodia leaders' gathering, Novo Foundations, Phnom Pheng.
Honenberger, P., 2007, “Le Negre et Hegel”: Fanon on Hegel, colonialism, and the dialectics of recognition', Human Architecture: Journal of the Sociology of SelfKnowledge 5(3), 15.

Innerchange.org, 2019, viewed 24 August 2019, from www.innerchange.org.

Joseph, S., 2016, 7 qualities of truly authentic people. Don't look at what people say, but how they say it, viewed 18 November 2019, from https://www. psychologytoday.com/us/blog/what-doesnt-kill-us/201608/7-qualities-trulyauthentic-people.

Kabongo, K.T.L., 2019a, 'From victimhood to hubs of (trans)formation and local agency: Re-imagining poor urban communities', Verbum et Ecclesia 40(1), a1998. https://doi.org/10.4102/ve.v40i1.1998

Kabongo, K.T.L., 2019b, 'Leadership development for missions in poor urban communities', HTS Teologiese Studies/Theological Studies 75(1), a5293. https:// doi.org/10.4102/hts.v75i1.5293

Kirk, A., 1997, The mission of theology and theology as mission, Gracewing Publishing, Valley Forge, PA.

Kouyoumdjian, H., 2012, Learning through visuals. Learning through visuals, viewed 21 November 2019, from www.psychologytoday.com

Kritzinger, J.N.J., 2019, Conversation. Unpublished comment: SAMS conference: Potchefstroom.

Learn through experience 2019, viewed 20 November 2019, from https://learnthrough experience.org/.

Linthicum, R.C., 2003, Transforming power: Biblical strategies for making a difference in your community, Intervarsity Press, Downers Grove, IL.

Mashabela, J.K., 2017, 'Africanisation as an agent of theological education in Africa', HTS Teologiese Studies/Theological Studies 73(3), a4581. https://doi.org/10.4102/ hts.v73i3.4581

Mbembe, A., 2007, 'Biko's testament of hope', in C. Van Wyk (ed.), We write what we like: Celebrating Steve Biko, pp. 135-148, Wits University Press, Johannesburg.

Mbembe, A., 2015, Decolonising knowledge and the question of the archive, viewed 06 November 2016, from https://wiser.wits.ac.sa/system/files/Achille $\% 20$ Mbembe $\% 20$ $-\% 20$ Decolonising $\% 20$ Knowledge $\% 20$ and $\% 20$ the $\% 20$ Question $\% 20$ of $\% 20$ the $\% 20$ Archive.pdf.

McMinn, L.G., 1998, 'Enclave adaptation, multiculturalism and evangelical Christian colleges', Research on Christian Higher Education 5, 23-52.

Myers, B.L., 2011, Walking with the poor: Principles and practices of transformational development, Orbis Books, Maryknoll, New York.

Naidoo, M., 2015, 'Transformative remedies towards managing diversity in South African theological education', HTS Teologiese Studies/Theological Studies 71(2), Art. \#2667, 7 pages. https://doi.org/10.4102/hts.v71i2.2667

Naidoo, M., 2016, 'Overcoming alienation in Africanising theological education', HTS Teologiese Studies/Theological Studies 72(1), Art. \#3062, 8 pages. https://doi. org/10.4102/hts.v72i1.3062

Niemandt, C.J.P., 2014, 'Emerging missional ecclesiology in the Dutch Reformed Church in South Africa and church polity', in A. Janssen \& L.J. Koffeman (eds.), Protestant church polity in changing contexts, Ecclesiological and historical contributions. Proceedings of the international conference, vol. 1, pp. 65-82, Utrecht, The Netherlands, 07-10 November 2011, Zürich, LIT-Verlag.

Niemandt, C.J. \& Beyers, J., 2017, “'Science of religion and missiology at the faculty of theology, University of Pretoria: Historical overview, theological discourses and future possibilities", in "Theology at the University of Pretoria - 100 years: (19172017) past, present and future"', Verbum et Ecclesia 38(4), a1663. https://doi. org/10.4102/ve.v38i4.1663

Niemandt, N., 2019, 'A missional hermeneutic for the transformation of theological education in Africa', HTS Teologiese Studies/Theological Studies 75(4), a5406. https://doi.org/10.4102/hts.v75i4.5406

Nyamnjoh, F.B., 2004, 'A relevant education for African development. Some epistemological considerations', Africa Development-Senegal 29(1), 161-184. https://doi.org/10.4314/ad.v29i1.22190

Pei, A., 2018, The minority experience. Navigating emotional and organizational realities, IVP Books, Downers Grove, IL.

Polit, D.F. \& Beck, C.T., 2008, Nursing research. Generating and assessing evidence for nursing practice, 8th edn., Lippincott Williams \& Wilkins, Hong Kong.

Ramphele, M., 2017, Dreams, betrayal and hope, Penguin Books, Cape Town.

Simon, C.A., 2019, Engaging the five senses to learn about our world, International Literacy International/ National Council of Teacher Education, Urbana, IL.

Shams, L. \& Seitz, A.R., 2008, 'Benefits of multisensory learning', Trends in Cognitive Sciences 12(11), 411-417.

Treichler, D.G., 1967, 'Are you missing the boat in training aid?', Film and Audio Visual Communication 1, 14-16.

University of Pretoria, 2019, 'Curriculum transformation framework', Unpublished policy document, University of Pretoria, Pretoria.

Van Niekerk, A.S., 2015, 'Guidelines for visits to households GSW 310 and 314', Unpublished paper, University of Pretoria, Pretoria.

Wortman, R., 1988, Using all the senses to learn, viewed 20 November 2019, from https://www.sd43.bc.ca. 